\title{
Pengaruh Online Trading Terhadap Kepuasan Nasabah Pt. Sucorinvest Central Gani Cabang Kediri
}

\author{
Edi Murdiyanto
}

\author{
Universitas Islam Kadiri - Kediri \\ edimurdiyanto@uniska-kediri.ac.id
}

\begin{abstract}
This research is aimed to measure the customers' satisfaction of PT Sucorinvest Central Gani branch Kediri, by the existemce of Online Trading application. The population of this research is all customers of PT Sucorinvest Central Gani branch Kediri. Technique of sampling used is purposive sampling, so it is taken 103 customers matching the criteria. This research uses Double Linear Regression to analyze the data. the result shows that there is influence of customers' satisfaction to the existence of online trading application. The other result found is some parts of variation of marketing including transaction fee, office location, employee, document such as transaction journal, and service process also have possitive significantly influence to the customers' satisfaction. On the other hand, this research cannot prove that stock exchange's products do not have possitive and significant influence to the customers' satisfaction.
\end{abstract}

Key words: Online Trading, variation of marketing, stock exchange.

\begin{abstract}
ABSTRAK
Penelitian ini bertujuan untuk mengukur tingkat kepuasan nasabah PT. Sucorinvest Central Gani Cabang Kediri, dengan adanya aplikasi Online Trading. Populasi penelitian ini adalah semua nasabah PT. Sucorinvest Central Gani cabang kediri, teknik pengambilan sampel menggunakan purposive sampling sehingga di temukan sampel 103 nasabah yang memenuhi kriteria. Teknik analisa menggunakan regrisi linier berganda, hasil penelitian menunjukkan adanya pengaruh kepuasan nasabah dengan adanya fasilitas online trading. Hasil lainnya di temukan bahwa beberapa bagian dari bauran pemasaran jasa meliputi harga berupa fee transaksi, lokasi kantor, pegawai, bukti fisik berupa laporan transaksi, dan proses pelayanan juga berpengaruh positif terhadap kepuasan nasabah. Sebaliknya, hasil penelitian ini tidak dapat membuktikan variabel produk pasar modal memiliki pengaruh signifikan terhadap kepuasan.
\end{abstract}

Kata kunci : Online Trading, bauran pemasaran jasa, pasar modal.

\section{LATAR BELAKANG}

Dalam perkembangannya marketing tidak hanya mengacu pada sektor perdagangan barang, sektor jasa juga berkembang sangat pesat. hal tersebut mengacu pada upaya untuk memenuhi kebutuhan pelanggan. di dasari pada perkembangan ekonomi global maka sangat memungkinkan persaingan di sektor jasa juga semakin meningkat. Schoell dan Gultinan (1992) dalam Tjiptono (1997:133). menyatakan bahwa sektor jasa sangat berkembang di tinjau dari beberapa factor. antara lain pertama Perkembangan teknologi sangat pesat termasuk teknologi informasi. kedua adanya pengaruh sektor jasa Berhadap aspek sektor yang lain secara terpadu. ketiga Persentase 
wanita masuk ke angkatan kerja semakin besar. keempat Tingkat harapan hidup semakin meningkat. kelima Produk-produk yang di butuhkan dan dihasilkan semakin kompleks dan terakhir adanya peningkatan kompleksitas kehidupan.

Perkembangan sektor jasa yang sangat pesat baik dari unit maupun ragamnya, maka dalam menciptakan pertukaran yang saling menguntungkan antara penyedia jasa, penyampai jasa dan pelanggan, sehingga memerlukan pemasaran yang harus dikelola dengan baik.

Pemasaran atau Marketing adalah seperangkat alat pemasaran terkendali yang menggunakan sebuah institusi untuk menghasilkan respon yang diinginkan dari berbagai target pasar. Sektor jasa menggunakan pendekatan 7P dalam rangka untuk memenuhi kebutuhan penyedia layanan oleh Jonathan Evvy $(2008 ; 288)$.

Berdasarkan definisi tersebut menunjukkan bahwa kegiatan pemasaran, terlebih pada produk jasa, haruslah fokus pada pelanggan. Fokus pada pelanggan berarti kepuasan pelanggan, kepuasan pelanggan adalah ringkasan keadaan psikologis yang dihasilkan ketika emosi digabungkan dengan perasaan pengalaman konsumsi sebelumnya (Oliver 1981 hal 27). Pelanggan yang puas diharapkan dapat membeli kembali di waktu-waktu mendatang, mereferensi teman untuk membeli dan menjadi agen promosi bagi perusahaan. Pelanggan yang memperoleh kepuasan menunjukkan pelanggan telah terpenuhi keinginan dan kebutuhannya. Keinginan dan kebutuhan pelanggan bervariasi. Terpecahkannya masalah pelanggan dengan membeli apa yang ditawarkan perusahaan berupa produk atau jasa dari yang diketahui melalui promosi produk, harga yang terjangkau, lokasi pembelian yang mudah dijangkau dan strategis, layanan yang menyenangkan, interaksi yang direspon baik perusahaan dan reputasi perusahaan serta citra merek dari produk. Komponen-komponen tentang produk, harga, tempat, promosi, orang, proses dan bukti fisik merupakan bauran pemasaran.

Bauran pemasaran yang terdiri dari produk, tempat, promosi dan penetapan harga ( Buchari Alma ; 2000 ) yang bersifat unik serta di rancang untuk menghasilkan pertukaran yang saling menguntungkan. Namun kini hal tersebut semakin berkembang tidak hanya dalam produk, promosi dan harga, namun juga mengenai tempat, orang, bukti fisik dan proses yang terkenal dengan konsep 7P. Kotler dan Keller di alih bahasa oleh Molan (2006). 
Industri jasa di Pasar Modal Indonesia, terutama perantra perdagangan efek ( Securities ) Fakhruddin (2008:35), sebagai industri jasa keuangan perusahaan efek ( Securities ) memberikan jasa perantara perdagangan efek di Indonesia. Perusahaan Efek dapat bertindak sebagai penjamin emisi efek (Under Writer), juga dapat bertindak selaku perantara perdagangan efek (broker / dealer), perusahaan efek memiliki peran penting dalam menunjang kesuksesan pasar modal, sebagai perantara (broker) dan sebagai pedagang (dealer), ikut menentukan kelancaran transaksi jual- beli untuk itu di tuntut bekerja jujur dan professional sehingga minat masyarakat untuk berinvestasi di pasar modal dapat di tingkatkan. ( Hariyani dan D.P.Serfianto 2010:114 )

Saat ini di Indonesia terdapat 115 Perusahaan Efek yang aktif melakukan kegiatan sebagai Perantara Perdagangan Efek (broker / dealer) atau Penjamin Emisi Efek(Under Writer), idx.co.id (2015), tentunya saling berkompetisi dengan kinerja yang berbedabeda sehingga pelanggan akan memilih perusahaan yang di anggap memiliki kinerja baik. Karena perusahaan efek adalah perusahaan jasa tentunya tidak lepas dari eleman bauran pemasaran jasa, untuk itu perusahaan efek tentunya membuat setrategi masingmasing untuk manarik pelanggan " investor " menggunakan jasanya dalam perdagangan efek di Pasar Modal Indonesia.

Dimasa sekarang perusahaan perantara perdagangan efek dalam fungsinya sebagai perantara perdagangan efek sudah menggunakan perdagangan secara online salah satunya adalah PT.Sucorinvest Central Gani yang merupakan salah satu perusahaan efek bertindak sebagai Perantara Perdagangan Efek (broker / dealer) dan juga Penjamin Emisi Efek (Under Writer) sejak di dirikan tahun 1989 Sucor (2013:3), PT. Sucorinvest Central Gani memiliki 30 Kantor perwakilan di beberapa kota besar di Indonesia. Dengan fasilitas online trading Sucorinvest Personal Online Tradingfasilitas (SPOT).

Tujuan penelitian ini adalah untuk menguji adanya fasilitas online trading apakah berdapak pada kepuasan nasabah PT. Sucorinvest Central Gani Cabang Kediri selain dari elemen bauran pemasaran jasa sebagai variabel independen. 


\section{KAJIAN PUSTAKA}

\section{Pengertian Pemasaran}

Menurut Stanton yang diterjemahkan oleh lemarto dan sadu sundaya (2009:10), pengertian pemasaran adalah sistem keseluruhan dari kegiatan usaha yang ditujukan untuk merencanakan, menentukan harga, mempromosikan dan mendistribusikan barang atau jasa yang dapat memuaskan kebutuhan kepada pembeli yang ada maupun pembeli potensial.

Menurut Kotler dan Keller ( $2012: 5$ ) pengertian pemasaran "Marketing is a societal prosess by which individuals and groups obtain what they need and want through creating, offering, and freely exchanging products and services of value with others " di artikan pemasaran adalah sebuah proses kemasyarakatan dimana individu dan kelompok memperoleh apa yang mereka butuhkan dan inginkan dengan menciptakan, menawarkan dan secara bebas menukarkan produk dan jasa yang bernilai dengan orang lain.

Dari definisi tersebut sama-sama menjelaskan pemasaran adalah kegiatan suatu organisasi dalam menciptakan, menawarkan, mempertukarkan produk atau jasa dengan menggunakan seperangkat alat pemasaran yang disebut bauran pemasaran agar dapat memuaskan kebutuhan pelanggan dengan mengelola hubungan pelanggan secara menguntungkan bagi organisasi.

\section{Pengertian dan karekteristik Jasa}

Menurut Djaslin Saladin (2007 :71) bahwa definisi jasa ialah kegiatan atau manfaat yang ditawarkan oleh satu pihak kepada pihak lain yang pada dasarnya tidak berwujud dan tidak menghasilkan kepemilikan apapun.

Indriyo Gutosudarmo (2008 : 221) Pengertian jasa ialah produk yang tidak berwujud yang biasanya berupa pelayanan yang di butuhkan oleh pelanggan.

William J. Stanton yang di kutip oleh Buchari Alma (2009:243) mendefinisikan jasa adalah sesuatu yang dapat diidentifikasikan secara terpisah dari wijud, ditawarkan untuk memenuhi kebutuhan

Pengertian jasa menurut Kotler yang dikutip pleh Ratih Hurriyanti (2010:27) ialah setiap tindakan atau kinerja yang ditawarkan oleh satu pihak ke pihak lain yang secara prinsip tidak berwujud dan tidak menyebabkan perpindahan kepemilikan. 
Dari definisi tersebut dapat simpulkan bahwa jasa merupakan kegiatan yang memberikan manfaat yang dapat ditawarkan kepada pelanggan atau pelanggan yang pada dasarnya miliki sifat tidak berwujud dan tidak dapat dipindah kepemilikannya.

Zeithaml dan Bitner (2000 :20) gambaran karakteristik jasa sebagai sesuatu yang tidak berwujud, tidak dapat di pisahkan, beraneka ragam, tidak tahan lama, tidak dapat di miliki.

\section{Pengertian Bauran Pemasaran Jasa}

Armstrong (1997) menyatakan bahwa marketing " mix as the set of controllable marketing variables that the firm bleads to produce the response it wants in the target market " dari definisi di atas dapat di artikan bahwa bauran pemasaran merupakan variabel - variabel terkendali yang digabungkan untuk menghasilkan tanggapan yang diharapkan dari pasar sasaran . untuk usaha jasa 7 unser marketing mix " marketing mix service " meliputi : Produc, price, Promotion, Place, Pertisipant "people", Proses, Physical Evidence.

Kotler (2002) menyatakan bahwa : Bauran pemasaran adalah seperangkat alat pemasaran yang di gunakan perusahaan untuk terus-menerus mencapai tujuan pemasarannya di pasar sasarannya, pasar pemasar biasanya menggunakannya sebagai alat untuk mendapatkan tanggapan yang diinginkan oleh perusahaan dari target pasar atas produk yang ditawarkan oleh perusahaan.

Philip kotler (2009:101) menyatakan bahwa marketing mix merupakan seperangkat alat pemasaran yang dugunakan perusahaan untuk terus menerus mencapai tujuan pemasarannya di pasar sasaran, mengklasifikasikan marketing mix menjadi emapat besar kelompok yang disebut dengan 4P tentang pemasaran yaitu Product (produk), Price ( harga), Place (tempat) dan promotion ( promosi ).

Jonathan Evvy (2008 :288) Marketing mix adalah seperangkat alat pamasaran terkendali yang menggunakan sebuah institusi untuk menghasilkan respon yang diinginkan dari berbagai target pasar. Sektor jasa menggunakan pendekatan $7 \mathrm{P}$ dalam rangka untuk memenuhi kebutuhan penyedia layanan pelanggan : produk, harga, tempat, promosi, orang, bukti fisik dan proses.

Menurut Bitner's dan Boom yang di kutip oleh Buchari Alma (2000;234) bauran pemasaran dalam produk jasa perlu di tambahi 3P, sehingga bauran pemasaran jasa menjadi 7P (Produk, Harga, Tempat, Promosi, Orang, Bukti fisik dan Proses). 


\section{Kepuasan Pelanggan}

Pengertian Kepuasan Pelanggan

Konsep kata kepuasan pelanggan berasal dari kata kepuasan (satisfaction) berasal dari kata latin "satis" (cukup baik, memadai) dan "fucio" (melakukan atau membuat) kepuasan dapat di artikan sebagai " upaya pemenuhan sesuatu" atau " membuat sesuatu memadai" (Hunt, 1977). Berdasarkan kajian literature kepuasan pelanggan secara intensif (Giese \& Cote : 2000) mengidentifikasi 20 definisi yang di acu dalam riset kepuasan pelanggan selama periode waktu 30 tahun, walaupun definisi-definisi tersebut bervariasi, kedua pakar tersebut menemukan kesamaan dari tiga komponen utama yaitu : 1). Kepuasan pelanggan merupakan respon ( emosional atau kognitif). 2). Respon tersebut mencakup fokus tertentu (ekspektasi, produk, pengalaman, konsumsi dan seterusnya). 3). Respon terjadi pada waktu teretentu (setelah konsumsi, setelah pemilihan produk atau jasa, berdasarkan pengalaman akumulatif dan lain-lain). Secara singkat kepuasan pelanggan terdiri atas tiga komponen : respon menyangkut fokus tertentu yang ditentukan pada waktu tertentu.

Menurut Zeithaml dan Bitner (2000:75) definisi kepuasan adalah : Respon atau tanggapan konsumen mengenai pemenuhan kebutuhan. Kepuasan merupakan penilaian mengenai ciri atau keistimewaan produk atau jasa, atau produk itu sendiri, yang menyediakan tingkat kesenangan konsumen berkaitan dengan pemenuhan kebutuhan konsumsi konsumen.

Sedangkan menurut Kotler sebagaimana di kutip oleh( Nasution ; 2004 ) menyatakan kepuasan pelanggan adalah tingkat perasaan seseorang setelah membandingkan kinerja atau hasil yang ia rasakah di bandigkan dengan dengan harapannya. (dalam Engel dkk, 1994) Konsumen yang merasa puas dengan nilai yang diberikan oleh produk atau jasa maka sangat besar kemungkinannya akan menjadi konesumen dalam waktu yang lama. Kepuadan pembelian di akhiri oleh perilaku sesudah pembelian dimana consume akan membeli lagi atau tidak, tergantung dari tingkat kepuasan yang didapatkan dari produk jasa tersebut ( dalam Tjiptono, 1999 ).

Sedangkan menurut Pasuraman, Zeithaml, dan Berry, mengemukakan bahwa kepuasan pelanggan adalah perasaan pelanggan terhadap satu jenis pelayanan yang didapatkannya . Lovelock menjelaskan bahwa kepuasan adalah keadaan emosional, reaksi pasca pembelian mereka dapat berupa kemarahan, ketidakpuasan, kejengkelan, 
kegembiraan atau kesenangan. Tidak mengherankan bahwa perusahaan telah menjadi terobsesi dengan kepuasan pelanggan, mengingat hubungannya yang langsung dengan kesetiaan pelanggan, pangsa pasar dan keuntungan. Schiffman dan Kanuk menandaskan bahwa kepuasan pelanggan merupakan perasaan seseorang terhadap kinerja dari suatu produk atau jasa yang dibandingkan dengan harapannya.

\section{Faktor yang mempengaruhi kepuasan pelanggan}

Karena kepuasan pelanggan sangat tergantung pada persepsi dan ekspektasi pelanggan, maka sebagai pemasok produk perlu mengetahui factor-faktor yang mempengaruhinya. Menurut Zeithaml dan Bitner (2000:75) ada empat faktor yang mempengaruhi persepsi dan ekspektasi pelanggan, yaitu sebagai berikut :

1. Apa yang didengar pelanggan dari pelanggan lainnya (word of mounth communication).Dimana hal ini merupakan faktor potensial yang menentukan ekspektasi pelanggan.Sebagai contoh, seorang pelanggan memiliki perusahaan yang di harapkan dapat memberikan pelayanan dengan kualitas tinggi berdasarkan rekomendasi teman-teman atau tetangganya.

2. Ekspektasi pelanggan sangat bergantung dari karakteristik individu dimana kebutuhan pribadi (personnel needs).

3. Pengalaman masa lalu (past experience) dalam menggunakan pelayanan dapat juga mempengaruhi tingkat ekspetasi pelanggan.

4. Komunikasi dengan pihak eksternal (external communication) dari pemberi layanan memainkan peranan kunci dalam membentuk ekspektasi pelanggan.Berdasarkan External communication, perusahan pemberi layanan dapat memberikan pesan-pesan secara langsung maupun tidak langsung kepada pelanggannya.Sebagai contoh dari pengaruh adanya external communication adalah harga di mana biaya pelayanan sangat berperan penting dalam membentuk ekspektasi pelanggan.

\section{Pengertian Online Trading PT.Sucorinvest Central Gani.}

Merupakan platform trading yang di ciptakan untuk memudahkan nasabah dalam bertransaksi saham kapan dan di mana saja. Layanan Sucorinvest Personal Online Trading (SPOT) bertujuan untuk membuka akses ke pasar modal bagi jutaan masyarakat Indonesia dan memberikan kenyamanan bagi nasabah untuk bertransaksi secara cepat dan mudah. Dengan latar belakang tersebut SPOT hadir sebagai platform 
yang inovatif, aman dan terpercaya bagi nasabah. Tersedia online trading reguler dan syariah.

\section{METODE PENELITIAN}

\section{Metode Pendekatan Penelitian}

Metode penelitian yang digunakan dalam penelitian ini adalah dengan pendekatan kuantitatif disktiptif, sehingga peneliti dapat menjelaskan secara sitematis tentang fakta-fakata yang diperolah saat penelitian yang dilakukan di PT Sucorinvest Central Gani cabang Kediri. Teknik pengambilan sampel menggunakan purposive sampling sehingga di temukan sampel 103 nasabah yang memenuhi kriteria. Teknik analisa menggunakan regrisi linier berganda, hasil penelitian menunjukkan adanya pengaruh kepuasan nasabah dengan adanya fasilitas online trading.

2. Lokasi Penelitian

Penelitian ini di lakukan di PT. Sucorinvest Central Gani Cabang Kediri, Jl. KH. Ahmad Dahlan No. 76 Kediri : adapun alasan penelitian dengan pertimbangan karena PT. Sucorinvest Central Gani adalah perusahaan Efek "securities " yang berdiri lebih dari 25 Tahun di Indonesia sudah memiliki 30 kantor perwakilan di seluruh Indonesia dan kantor perwakilan di Kediri sudah beroperasi 2 Tahun sehingga jumlah nasabah memenuhi criteria penelitian, dan juga karena focus penelitian yang akan di teliti adalah nasabah yang mengunakan online trading dan kantor perwakilan Kediri fokus pada pelayanan nasabah online trading sehingga dianggap memenuhi criteria penelitian.

\section{HASIL DAN PEMBAHASAN}

\section{Deskripsi Responden}

Responden dalam penelitian ini adalah pelanggan online trading di PT. Sucorinvest Central Gani yang daftar sebagai pengguna aplikasi Sucorinvest Personal Online Trading (SPOT), melakukan pengisian dana investasi dan sudah melakukan pembelian ataupun penjualan saham melalui aplikasi SPOT.

Dari hasil penelitian diperoleh temuan sebanyak 137 pelanggan yang melakukan investasi saham yang menggunakan SPOT, sehingga penelitian dilakukan terhadap 137 pelanggan, dengan penyebaran kuesioner di peroleh data responden sebagai berikut : 
Tabel : Data Responden

\begin{tabular}{|l|l|l|}
\hline No. & Jumlah Responden & Keterangan \\
\hline 1. & 103 Pelanggan & Mengisi Kuosioer \\
\hline 2. & 7 Pelanggan & Kuesioner tidak di isi lengkap atau tidak di isi \\
\hline 3. & 27 Pelanggan & $\begin{array}{l}\text { Pelanggan tidak dapat di mintai pengisian } \\
\text { Kuesioner dengan berbagai alasan. }\end{array}$ \\
\hline
\end{tabular}

Sumber :Data primer di oleh, 2015

Dari data di atas di peroleh responden yang dapat di mintai pendapat dan tanggapan tentang materi penelitian sebanyak 103 responden, sedangkan sisanya 7 responden tidak dapat di teliti karena tidak melakukan pengisian kuesioner dengan benar dan juga sebanyak 27 responden tidak dapat di mintai pengisian kuesioner dengan berbagai sebab, sehingga penelitian ini di fokuskan pada 103 responden.

\section{Uji Validitas Instrumen penelitian}

Instrumen yang di gunakan sebagai alat pengumpulan data, di uji terlebih dahulu dengan uji validitas sehingga instrument bener-benar bebas dari kesalahan sistematis dan random, instrument yang valid dapat di gunakan untuk mengukur apa yang akan di ukur. Item di nyatakan valid jika koefisien korelasi $\mathrm{r}$ hitung $\geq \mathrm{r}$ tabel, $\mathrm{r}$ tabel dapat dilihat pada tabel statistic dengan uji 2 sisi, pada $\mathrm{N}=103(d f=n-k), \mathrm{df}=103-7=$ $96 \mathrm{r}$ tabel nilainya $=0,1986$ dengan alpha sebesar $\alpha=5 \%(0,05)$.

\section{Uji Reliabilitas}

Pengujian reliabilitas dalam dilakukan untuk menguji konsistensi alat ukur, apakah hasilnya konsisten atau tidak jika pengukuran di ulang, istruman penelitian yang tidak reliable maka tidak konsiten untuk pengukuran sehigga hasil pengukuran tidak dapat di percaya. Dalam penelitian menggunakan metode Cronbach Alpha.

Menurut Priyatno (2012: 110) dikatakan reliable jika Cronbach”s Alpha lebih besar dari 0,6. Hasil uji reliabilitas dalam penelitian ini di ringkas pada tabel berikut ini : 
Tabel: Hasil Uji Reliabilitas

\begin{tabular}{|l|l|l|l|}
\hline Variabel & $\begin{array}{l}\text { Koefisien } \\
\text { Alpha } \\
\text { Cronbach }\end{array}$ & Hasil & Keterangan \\
\hline X1 & 0,626 & $\geq 0,6$ & Reliabel \\
\hline $\mathbf{X 2}$ & 0,660 & $\geq 0,6$ & Reliabel \\
\hline X3 & 0,624 & $\geq 0,6$ & Reliabel \\
\hline $\mathbf{X 4}$ & 0.783 & $\geq 0,6$ & Reliabel \\
\hline X5 & 0,619 & $\geq 0,6$ & Reliabel \\
\hline X6 & 0,677 & $\geq 0,6$ & Reliabel \\
\hline $\mathbf{X 7}$ & 0,659 & $\geq 0,6$ & Reliabel \\
\hline Y & 0,678 & $\geq 0,6$ & Reliabel \\
\hline
\end{tabular}

Sumber data : data primer di oleh tahun 2016

Berdasarkan tabel 15 di peroleh keseluruhan data dari variabel Produk dimana semua mempunya koefisiensi alpha crobach yang cukup besar yaitu di atas 0,6 atau dapat di katakana semua variabel koesioner adalah reliabel. Sehingga untuk selanjutnya item-item pada variabel tersebut dapat di gunakan sebagai alat ukur.

\section{Uji Asumsi Klasik}

1. Uji Multikolinearitas

Uji ini lakukan bertujuan untuk menguji apakah dalam model regresi di temukan adanya korelasi antara variabel bebas dengan melihat apakah ada hubungan linier yang sempurna atau tidak, untuk mendeteksi hubungan tersebut dapat melihat VIF dari hasil regresi berikut ini :

Tabel 24 Pengujian Multikolinearitas Coefficients ${ }^{a}$

\begin{tabular}{lll} 
Model & $\begin{array}{l}\text { Collinearity Statistics } \\
\text { Tolerance }\end{array}$ & VIF \\
\hline 1 Produk & .922 & 1.085 \\
Harga & .903 & 1.107 \\
Lokasi & .604 & 1.655 \\
Promosi & .924 & 1.083 \\
Orang & .601 & 1.663 \\
Bukti fisik & .946 & 1.057 \\
Proses & .879 & 1.138 \\
\hline
\end{tabular}

Dependent Variable: Kepuasan pelanggan

Sumber : data primer dioleh 2016 
Dari tabel 24 di ketahui bahwa model regresi tidak mengalami gangguan multikolinearitas dalam model regresi. Hal ini ditunjukkan dari nilai VIF dari masing-masing yang terdiri dari :variabel produk (X1) 1.085, Harga $\left(\mathrm{X}_{2}\right)$ 1.107, Lokasi ( $\left.\mathrm{X}_{3}\right) 1.665$, Promosi ( $\left.\mathrm{X}_{4}\right)$ 1.083, Orang $\left(\mathrm{X}_{5}\right)$ 1.663, Bukti fisik ( $\left.\mathrm{X}_{6}\right) 1.057$ dan Proses $\left(\mathrm{X}_{7}\right) 1.138$ nilai VIF kuran dari 10 pengujian ini menunjukkan bahwa antara variabel independent atau bebas satu sama lain saling berhubungan atau tidak terjadi multikolinearitas.

2. Uji Normalitas.

Uji normalitas di lakukan dengan cara melihat sebaran data titik pada sumbu diagonal pada gratik normal propability plot ( $P$-P Plot) yang menbandingkan distribusi kumulatif dari distribusi normal. Jika distribusi data normal, maka garis yang menggambarkan data sesungguhnya akan mengikuti garis yang diagonal. Hasil outpus SPSS for Windows V. 16.0. untuk uji normalitas di tunjukkan dalam gambar sebagai berikut :

\section{Gambar 3}

\section{Hasil Uji Normalitas}

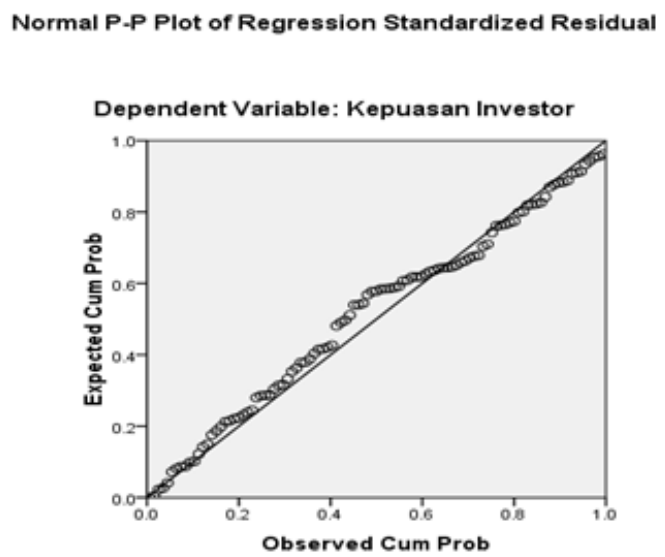

Berdasarkan gambar 2 dapat dijelaskan bahwa data menyebar di sekitar garis diagonal dan mengikuti arah garis diagonal. Oleh karena itu dapat dinyatakah bahwa data dalam variabel-variabel ini berdistribusi normal. Dengan demikian produk regresi menemukan asumsi normalitas, karena hasil jawaban responden tentunya : Produk, Harga, Lokasi, Promosi, Orang, Bukti fisik, proses dan kepuasan pelanggan di antara garis diagonal. 


\section{Uji Auto Korelasi}

Uji Autokorelasi bertujuan untuk menguji apakah dalam suatu model regresi lininer ada autokorelasi antara kesalahan atau problem autokorelasi. Model regresi yang baik adalah regresi yang bebas dari autokorelasi di sajikan pada tabel berikut ini :

\section{Tabel 25}

\section{Tabel auto Korelasil}

\begin{tabular}{|l|r|r|r|r|r|}
\hline Model & \multicolumn{1}{|c|}{$\mathrm{R}$} & R Square & \multicolumn{1}{c|}{$\begin{array}{c}\text { Adjusted } \mathrm{R} \\
\text { Square }\end{array}$} & $\begin{array}{c}\text { Std. Error of the } \\
\text { Estimate }\end{array}$ & Durbin-Watson \\
\hline 1 & $.829^{3}$ & .687 & .663 & 1.239 & 1.775 \\
\hline
\end{tabular}

a. Predictors: (Constant), Proses, Produk, Bukti fisik, Promosi, Harga, Lokasi, Orang

b. Dependent Variable:Kepuasan pelanggan

Sumber : data primer di oleh 2016

Berdasarkan table di atas nilai Durbi Watson (DW) yang dihasilkan adalah 1.775 dan memiliki nilai di atara - 2 sampai dengan +2 sehingga dapat di sipulkan bahwa, tidak terjadi autokorelasi.

\section{Analisis Regresi linier Berganda}

Metode analisis dalam penelitian ini menggunakan regresi lininer berganda (Multiple regression) bertujuan untuk mengetahui pengaruh pengaruh variabel independen terhadap variabel dependen. Ringkasan hasil pengolahan data dengan menggunakan program SPSS for Windows V. 16.0. adalah sebagai berikut :

\section{Tabel 26}

Ringkasan Hasil Regresi

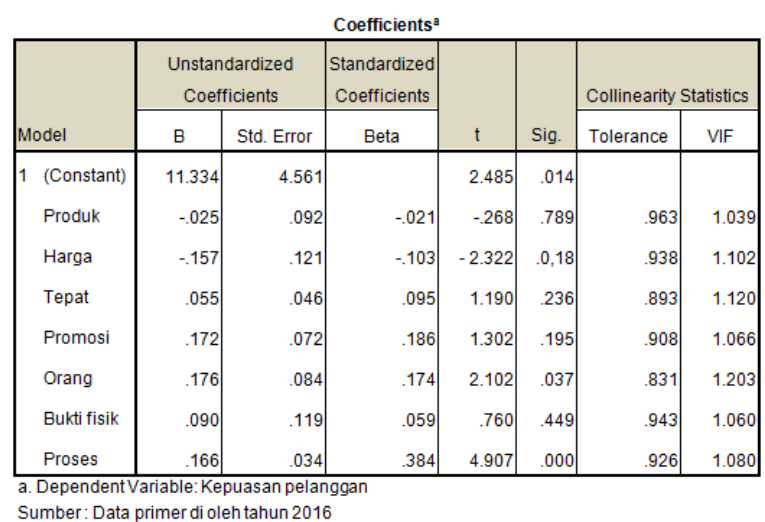

Berdasarkan hasil tersebut apagila di tulis dalam bentuk standardized dari persamaan regresinya adalah sebagai berikut : 


$$
\begin{aligned}
Y= & a+b_{1} X_{1}+b_{2} X_{2}+b_{3} X_{3}+b_{4} X_{4}+b_{5} X_{5}+b_{6} X_{6}+b_{7} X_{7} \\
Y= & 11,334+(-0,025) X_{1}+(-0,157) X_{2}+(0,055) X_{3}+(0.172) X_{4}+(0,176) X_{5} \\
& +(0,90) X_{6}+(0,166) X_{7}
\end{aligned}
$$

Persamaan regresi berganda tesebut di jelaskan sebagai berikut :

a Nilai konstanta (a) sebesar 11,334. Artinya apabila variabel produk $\left(\mathrm{X}_{1}\right)$, Harga $\left(X_{2}\right)$, Lokasi ( $\left.X_{3}\right)$, Promosi ( $\left.X_{4}\right)$, Orang $\left(X_{5}\right)$, Bukti fisik $\left(X_{6}\right)$ dan Proses $\left(\mathrm{X}_{7}\right)$ di asumsikan tidak memiliki pengaruh sama sekali $(=0)$, maka pengaruh kepuasan pelanggan sebesar $(11,745)$.

b Variabel produk $\left(\mathrm{X}_{1}\right)$ miliki koefisiensi regresi sebesar (- 0,025). Ini menunjukkan bahwa jika variabel produk naik 1 satuan, sedangkan variabel harga, lokasi, promosi, orang, bukti fisik, dan proses tetap maka kepuasan pelanggan (Y) akan turun sebesar 0,025 satuan.

c Variabel Harga $\left(\mathrm{X}_{2}\right)$ mimiliki koefisiensi sebesar $(-0,157)$. Artinya apabila variabel harga naik 1 satuan, sedangkan variabel prosuk, lokasi, promosi, orang, bukti fisik, dan proses tetap, maka kepuasan pelanggan ( Y ) akan turun sebesar 0.167 satuan.

d Variabel Lokasi $\left(\mathrm{X}_{3}\right)$ memiliki koefisiensi regresi sebesar 0,055. Artinya apabila variabel lokasi naik 1 satuan, sedangkan variael produk, harga, promosi, orang, bukti fisik, dan proses tetap, maka kepuasan pelanggan ( Y ) akan naik sebesar 0,055 satuan .

e Variabel promosi $\left(\mathrm{X}_{4}\right)$ memiliki koefisiensi regresi sebesar 0,172. Artinya apabila variabel promosi naik 1 Satuan, sedangkan variabel produk, harga, lokasi, orang, bukti fisik, dan proses tetap tetap, maka kepuasan pelanggan ( Y ) akan turun sebesar 0,172 satuan.

1) Variabel Orang $\left(X_{5}\right)$ memiliki koefisiensi regresi sebesar 0,176. Artinya apabila variabel Orang naik 1 Satuan, sedangkan variabel produk, harga, lokasi, promosi, bukti fisik, dan proses tetap, maka kepuasan pelanggan ( Y ) akan naik sebesar 0,176 satuan.

2) Variabel Bukti fisik $\left(X_{6}\right)$ memiliki koefisiensi regresi sebesar 0,090. Artinya apabila variabel Bukti fisik naik 1 Satuan, sedangkan variabel produk, harga, lokasi, promosi,Orang dan proses tetap, maka kepuasan pelanggan ( Y ) akan naik sebesar 0,090 satuan. 
3) Variabel Proses $\left(X_{7}\right)$ memiliki koefisiensi regresi sebesar 0,166. Artinya apabila variabel proses naik 1 Satuan, sedangkan variabel produk, harga, lokasi, promosi,Orang dan Bukti fisik tetap, maka kepuasan pelanggan ( Y ) akan naik sebesar 0,166 satuan.

Berdasarkan standardized coefficeents di ketahui bahwa di antara variabel produk, harga, lokasi, promosi, orang, bukti fisik, dan proses yang memiliki pengaruh dominan terhadap kepuasan pelanggan online trading "SPOT" dalam bertransaksi saham di Pasar Modal Indonesia melalui perantara PT. Sucorinvest Central Gani Cabang Kediri adalah : Orang dengan standar deviasi sebesar 0,218 artinya jika variabel orang naik satu satuan kepuasan akan mengalami kenaikan sebesar 0,218 satuan dan yang memiliki pengaruh dominan lain adalah variabel harga dengan standar deviasi - 0,161 artinya jika harga di naikkan 1 satuan maka kepuasan jutru mengalami penurunan sebesar 0,161 satuan.

\section{Uji Hipotesis}

Pengajuan hipotesis dilakukan dengan menggunakan uji $\mathrm{F}$ dan uji t. Tabel distribusi F merupakan tabel bantuan jika menggunakan statistic uji F.

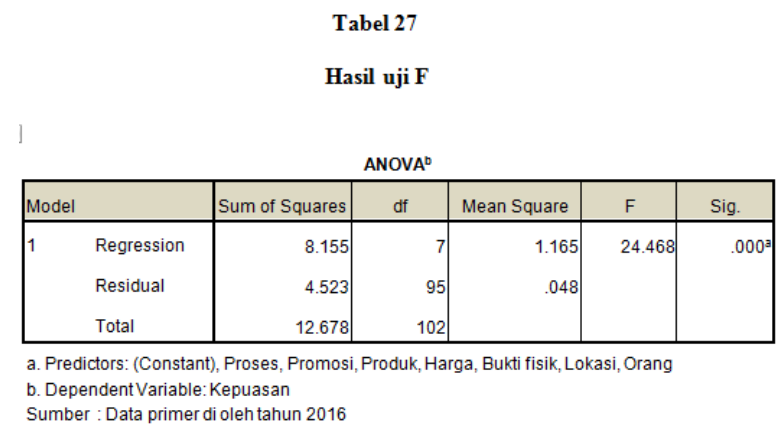

Uji F di gunakan untuk mengetahui apakah semua variabel bebas yang dimasukkan dalam model regresi mempunyai pengaruh secara bersama-sama terhadap variabel terikat. Adapun dasar dalam pengambilan keputusan adalah sebagai berikut :

1) Jika ( $\left.F_{\text {hitung }}>F_{\text {tabel }}\right)$ atau nilai Sig kurang dari 0,05 maka Ho di tolak Ha di terima, hal ini berarti secara simultan variabel beebas perpengaruh signifikan terhadap variabel terikat.

2) Jika ( $F_{\text {hitung }}<F_{\text {tabel }}$ ) atau nilai Sig lebih dari 0,05 maka Ho diterima Ha tolak, hal ini berarti secara siultan variabel bebas tidak berpengaruh signifikan terhadap variabel terikat. 
3) Penentuan Ftabel ( df1 = k-1 ) dan (df2 =n-k) jumlah Variabel penelitian 8 variabel : 7 Variabel dependen dan 1 Variabel Independen $=8 .($ df $1=7-1=6)$ dan $(\operatorname{df} 2=$ $103-7=96)$.

Hipotesis Berdasar Uji F pada Tabel 26 di atas diketahui besaran $\mathrm{F}$ hitung $(24,468)$ $>F_{\text {tabel }}(2,19)$ dan $\operatorname{Sig}=0,000$ maka Ho ditolak dan Ha diterima . Hal ini berarti secara simultan variabel produk, harga, lokasi, promosi, orang, bukti fisik dan proses berpengaruh signifiikan terhadap kepuasan pelanggan.

\section{Uji t}

Uji t di lakukan untuk mengetahui pengaruh variabel bebas secara parsial atau indivual terhadap variabel terikat. Dinyatakan Ho akan di tolak dan Ha akan di terika jika $t_{\text {hitung }}>t_{\text {tabel }}$ atau nilai Sig. output $>0,05$. Hal ini berarti Ho di tolak dan Ha di terima yang artinya tidak terdapat pengaruh yang signifikan variabel bebas terhadap bariabel terikat.

Pengujian hipotesis dengan $\alpha=5 \%$. Penentuan Ftabel ( df1 $=k-1)$ dan (df2 =n-k) jumlah Variabel dependen : 7 Variabel dependen dan 1 Variabel Independen. ( $\mathrm{df} 1=7$ $-1=7)$ dan $($ df $2=103-7=96)$.

Prosedur penyajian de sebagai berikut :

1) Diketahui besaran $t$ hitung $(-0.268)<t_{\text {tabel }}(1,985)$ dan $\operatorname{Sig}=0,789>0,05$ maka Ho di terima dan Ha di tolak. Dapat di simpulkan bahwa produk tidak berpengaruh signifikan terhadap kepuasan pelanggan.

2) Diketahui besaran $t$ hitung $(-2.322)>t_{\text {tabel }}(1,985)$ dan $\operatorname{Sig}=0,018<0,05$ maka Ho di tolak dan Ha di terima. Dapat di simpulkan bahwa harga berpengaruh signifikan terhadap kepuasan pelanggan.

3) Diketahui besaran $t_{\text {hitung }}(1,190)<t_{\text {tabel }}(1,985)$ dan $\operatorname{Sig}=0,236>0,05$ maka Ho di terima dan Ha di tolak. Dapat di simpulkan bahwa Tempat tidak berpengaruh signifikan terhadap kepuasan pelanggan.

4) Diketahui besaran $t_{\text {hitung }}(1,302)<t_{\text {tabel }}(1,985)$ dan $\operatorname{Sig}=0,195>0,05$ maka Ho di terima dan Ha di tolak. Dapat di simpulkan bahwa promosi tidak berpengaruh signifikan terhadap kepuasan pelanggan. 
5) Diketahui besaran $t_{\text {hitung }}(2.102)<t_{\text {tabel }}(1,985)$ dan $\operatorname{Sig}=0,037>0,05$ maka Ho di tolak dan $\mathrm{Ha}$ di di terima. Dapat di simpulkan bahwa orang berpengaruh signifikan terhadap kepuasan pelanggan.

6) Diketahui besaran $t_{\text {hitung }}(0,760)<t_{\text {tabel }}(1,985)$ dan $\operatorname{Sig}=0,449>0,05$ maka Ho di terima dan Ha di tolak. Dapat di simpulkan bahwa bukti fisik tidak berpengaruh signifikan terhadap kepuasan pelanggan.

7) Diketahui besaran $t_{\text {hitung }}(4,907)<t_{\text {tabel }}(1,985)$ dan $\operatorname{Sig}=0,000<0,05$ maka Ho di tolak dan Ha di terima. Dapat di simpulkan bahwa proses berpengaruh signifikan terhadap kepuasan pelanggan.

\section{PEMBAHASAN}

1. Pengaruh Produk, Harga, Tempat, Orang, Bukti fisik, Proses secara bersama-sama berpengaruh positif dan signifikan terhadap kepuasan pelanggan Perusahaan Efek di PT. Sucorinvest Central Gani cabang Kediri.

Hasil analisis dalam penelitian ini menunjukkan gambaran bahwa bauran pemasaran jasa yang terdiri dari Produk, Harga, Tempat, Orang, Bukti fisik, Proses berdasarkan dari respon responden tidak semuanya memiliki pengaruh positif dan signifikan terhadap kepuasan pelanggan Online trading di PT.Sucorinvest Central Gani cabang Kediri dari variabel tersebut yang memiliki pengaruh positif dan signifikan adalah :

a) Variabel proses yang terdiri dari item : (1.) Proses aktif pelanggan online trading yang melakukan investasi saham melalui perusahaan prantara perdagangan PT. Sucorinvest Central Gani cabang Kediri. (2.) Proses keterlibatan aktif dalam memberikan saran dan kritik untuk perbaika kinerja perusahaan. (3.) Proses pemberlakuan aturan yang berurientasi pada keamanan nasabah. (4.) Proses pemberlakuan aturan yang berurientasi pada kenyamanan nasabah. (5.) Proses kebijakan perusahaan ketika nasabah kesulitan dalam keterlambatan tagihan pembayaran saham. (6.) Proses kebijaksanaan memberikan kelonggaran waktu dalam penyelesaian transakasi yang dilakukan nasabah. Responden menganggap bahwa proses pelayanan akan membuktikan kenyamanan dan keamanan 
yang diupayakan oleh perusahaan dilakukan dengan konsisten atau tidak, sehingga pelanggan dari proses tersebut akan merasakan kepuasan, karena mendapatkan yang lebih dari yang diharapkan oleh pelenggan.

b) Kedua yang memiliki pengaruh positif dan signifikan adalah variabel orang yang terdiri dari item (1.) Personel karyawan yang kompeten, (2.) Personel karyawan yang professional, (3.) Sikap prilaku yang ramah, (4.) Sikap prilaku yang sopan santun, (5.) Kerapian dalam penampilan, (6.) Karakter pribadi yang menarik, (7.) Sikap simpatik dalam pelayanan, (8.) adanya empati dalam pelayanan. dari item tersebut responden menganggap memiliki pengaruh penting terhadap kepuasan yang pelanggan rasakan.

c) Variabel ketiga yag memiliki hubungan signifikan terhadap kepuasan pelanggan adalah variabel harga dengan item : (1.) Fee perdagangan terjangkau, (2.) Fee perdagangan yang kompetitif, (3.) Fee potongan khusus berdasarkan jumlah value transaksi, (4) Fee potongan khusus berdasarkan jumlah volume traksaksi, memiliki pengaruh signifikan negative.

d) Sedangkan berdasarkan jawaban responden untuk variabel yang tidak memiliki hubungan signifikan terhadap kepuasan pelangggan online trading adalah variabel produk, tempat, promosi dan bukti fisik.

\section{Produk berpengaruh positif dan signifikan terhadap kepuasan pelanggan online trading di PT. Sucorinvest Central Gani cabang Kediri.}

Dari jawaban responden variabel produk tidak berpengaruh signifikan terhadap kepuasan pelanggan. pelanggan memandang produk burupa sistem online trading "Sucorinvest Personal online Trading" meliputi mutu dan kwalitas sistem online, penampilan atau fitur online trading dan juga pilihan yang di berikan oleh perusahaan penyedia layanan online trading PT. Sucorinvest Central Gani tidak memiliki pengaruh signifikan terhadap kepuasan yang di rasakan oleh pelanggan.

Pelanggan ternyata menganggap jika mutu dinaikkan justru khawatir sistem online trading akan sulit di akses dan koneksi tidak setabil karena akan membutuhkan koneksi internet yang lebih cepat karena tidak semua pelanggan 
online trading memiliki jaringan internet yang kuat, pelanggan juga khawatir jika penampilan di rubah justru aka sulit untuk di operasikan oleh pelanggan karena sudah terbiasa dengan penampilan sistem online trading saat ini dan dengan pilihan aplikasi online trading yang terdiri dari sistem online trading yang bersifat konfensional dan syariah sudah dianggap cukup mewakili dari kebutuhan dari pelanggan.

3. Harga berpengaruh negatif dan signifikan terhadap kepuasan pelanggan online trading di PT. Sucorinvest Central Gani cabang Kediri.

Variabel harga dengan item : Fee perdagangan terjangkau, Fee perdagangan yang kompetitif, Fee potongan khusus berdasarkan jumlah value transaksi, Fee potongan khusus berdasarkan jumlah volume traksaksi, dianggap memiliki pengaruhi signifikan terhadap kepuasan pelanggan online trading PT. Sucorinvest Central Gani cabang Kediri.

Pengaruh tersebut memiliki pengaruh sifnifikan negative, karena pelanggan menganggap jika harga "fee" di naikkan justru kepuasan pelanggan online trading akan turun karena pelanggan akan merasa di bebani oleh biaya yang lebih mahal.

\section{Tempat berpengaruh positif dan signifikan terhadap kepuasan pelanggan} online trading di PT. Sucorinvest Central Gani cabang Kediri.

Hasil penelitian menunjukkan bahwa variabel tempat tidak berpengaruh positif dan signifikan namun memiliki nilai jawaban responden yang besar sehingga pemilihan tempat dengan melihat jangkauan, strategis dan lingkungan yang nyaman menjadi pertimbangan dalam menentukan kantor perwakilan PT. Sucorinvest Central Gani.

Dengan penentuan yang tidak melihat dari pertimbangan tersebut mungkin saja pelanggan jika membutuhkan pelayanan langsung oleh pegawai PT. Sucorinvest Central Gani akan kesulitan mencari lokasi perusahaan, sehingga justru akan menjadikan mereka tidak puas. 


\section{Promosi berpengaruh positif dan signifikan terhadap kepuasan pelanggan} online trading di PT. Sucorinvest Central Gani cabang Kediri.

Hasil penelitian memang promosi tidak memiliki hubungan signifikansi dengan kepuasan, namun promosi dapat menjadi pertimbangan seorang pelanggan. Untuk melakukan pembelian, karena dengan adanya promosi informasi perusahaan dapat di ketahui oleh pelanggan.

Promosi juga dilakukan oleh pelanggan, hal tersebut terjadi ketika pelanggan merasa puas maka justru pelanggan akan menjadi media efektif dalam promosi penjualan baik promosi bersifat informasi ataupun promosi bersifat promosi berupa saran untuk melakukan pembelian, terutama pada pihak yang di kenal oleh pelanggan.

\section{Orang berpengaruh positif dan signifikan terhadap kepuasan pelanggan} online trading di PT. Sucorinvest Central Gani cabang Kediri.

Hasil penelitian terdapat hasil hubungan positif dan signifikan variabel orang berupa personal yang kompeten dan professional, sikap prilaku yang ramah dan sopan, penampilan rapih dan menarik serta hubungan antar pribadi yang simpatik dan empati, dinilai pelanggan dapat membuat puas pelanggan.

Pelanggan mengganggap hubungan antar pribadi yaitu hubungan pegawai dengan pelanggan yang baik di karenakan sikap ramah dan sopan dapat menjadikan pelanggan merasa puas atas pelayanan. Apalagi jika sikap tersebut dilakukan oleh pegawai yang profesional dan kompeten maka masalah yang di hadapi oleh pelanggan akan mudah teratasi.

Adanya sikap simpatik dan empati juga memberikan kontribusi besar terhadap kepuasan yang di rasakan oleh pelanggan, terutama jika pelanggan merasa ada masalah atau kesulitan semisal mengalami kerugian investasi. Dengan adanya sikap simpatik dan empati yang di tunjukkan pegawai perusahaan perantara PT.Sucorinvest Central Gani akan meringankan beban kerugian yang di derita. Terkadang justru pelanggan tidak mempermasalahkan atas kerugian investasi saham karena pelanggan menganggap kerugian adalah bagian dari resiko yang ditanggung dalam investasi, justru mereka akan merasa puas atas pelayanan yang diberikan oleh pegawai perusahaan perantara, sehingga tercipta hubungan kerjasama yang erat antara pelanggan dan pegawai. 
7. Bukti fisik berpengaruh positif dan signifikan terhadap kepuasan pelanggan online trading di PT. Sucorinvest Central Gani cabang Kediri.

Hasil penelitian di nilai bahwa bukti fisik meliputi fasilitas fisik dan bukti fisik berupa portofolio investasi dan laporan transaksi di nilai tidak memiliki hubungan positif dan signifikan yang berarti terhadap kepuasan pelanggan.

pelanggan menganggap bukti fisik berupa fasilitas fisik kantor dan segala fasilitasnya adalah pendukung semata. Pelanggan juga menggap bukti fisik berupa portofolio investasi dan laporan transaksi adalah bukti yang memang wajib di berikan oleh perusashaan perantara perdagangan ketika pelanggan melakukan transaksi, sehingga hal tersebut di anggap biasa.

\section{Proses berpengaruh positif dan signifikan terhadap kepuasan pelanggan} online trading di PT. Sucorinvest Central Gani cabang Kediri.

Hasil penelitian variabel proses memiliki pengaru yang positif dan signifikan terhadap kepuasan yang pelanggan rasakan, dengan proses keterlibatan pelanggan langsung dalam perdagangan, kebijakan, kebijaksanaan serta alur kegiatan transaksi dan pelayanan transaksi saham.

Pelanggan menganggap proses keterlibatan akan menciptakan hubungan dengan pegawai sehingga semua bisa di kemunikasikan secara langsung, ketika pelanggan membutuhkan informasi pelanggan akan dengan mudah meminta kepada pegawai, ketika pelanggan mengalami kesulitasn operasional produk akan dapat di komunikasikan langsung kepada pegawai.

Proses dianggap sebagai penghubung antara semua variabel dari variabel produk, pelanggan bisa berkomunikasi tentang produk dengan pegawai secara personal dan lebih detail, proses juga menghubungkan variabel tempat karena dengan proses, pelanggan ketika berkunjung ke lokasi kantor perwakilan PT. Sucorinvest Central Gani cabang Kediri pelanggan tidak akan merasa canggung justru akan merasa nyaman karena akan di layani oleh pegawai yang sudah di kenal, masalah harga dapat dikomunikasikan, bukti fisik dapat diminta ketika pelanggan tidak sempat membuka laporan di email. Dari proses tersebut pelanggan akan merasakan kepuasan, justru pelanggan yang merasa puas akan menjadi agen promosi efiktif dan efisien bagi perusahaan. 


\section{KESIMPULAN DAN SARAN}

\section{a. Kesimpulan}

Berdasarkan hasil penelitian, analisis data dan pembahasan yang telah di lakukan, dapat di tarik kesimpulan sebagai berikut :

1. Bauran pemasaran jasa terdiri dari produk, harga, tempat, promosi, orang, bukti fisik dan proses . yang memiliki pengaruh paling signifikan terhadap kepuasan pelanggan Online Trading di PT. Sucorinvest Central Gani adalah proses yang terbentuk dari :

a) Proses keterlibatan pelanggan dalam mengikuti perkembangan bursa efek Indonesia, berperan aktif dalam memberikan saran kepada perusahaan efek jika ada yang dirasakan oleh pelanggan tidak sesuai.

b) Proses penerapan kebijakan perusahaan yang di komunikasikan oleh perusahaan kepada pelanggan dengan komunikasi yang baik dalam bantuk kebijakan atau kebijaksanaan pelanggan yang mempengaruhi kepuasan secara signifikan.

c) Proses alur kegiatan yang sist $\cdots \ldots$ konsisten sehingga pelanggan tidak merasa bingung dengan alu pelayanan yang di lakukan oleh perusahaan hal ini dirasa pelanggan yang memiliki pengaruh signifikan terhadap kepuasan yang mereka rasakan.

2. Variabel ke dua yang memiliki pengaruh signifikan terhadap kepuasan pelanggan online trading PT. Sucorinvest Central Gani cabang Kediri adalah harga yang terbentuk dari :

1) Penetanpan fee perdagangan terjangkau dan kompetitif memberikan kontribusi signifikan terhadap kepuasan yang di rasakan oleh pelanggan online trading di PT.Sucorinvest Central Gani cabang Kediri, pengaruh terebut bersifat signifikan negatife. Pelanggan beranggapan jika harga dinaikkan maka pengaruh terhadap kepuasan pelanggan akan mengalami penurunan.

2) Penetapan fee khusus dengan penetapan fee khusus berdasarkan jumlah besaran "value" transaksi dan jumlah volume transaksi memberikan kontribusi kepuasan signifikan yang di rasakan oleh pelanggan. Pelanggan 
beranggapan jika fee khusus di turunkan dengan alasan tersebut maka kepuasan pelanggan akan mengalami kenaikan.

Dari keduanya bentuk kepuasan yang di rasakan oleh pelanggan, pengaruhnya dari harga adalah bersifat negatife signifikan. Pelanggan beranggapan jika fee perdagangan semakin murah kemuasan yang mereka rasakan terhadap produk Online Trading samakin mereka rasakan.

3. Variabel ke tiga yang memiliki pengaruh signifikan terhadap kepuasan yang di rasakan oleh pelanggan selanjutnya adalah variabel orang dimana di bentuk dari

a) Personal yang kompeten dan professional memiliki pengaruh signifikan terhadap kepuasan yang di rasakan. Artinya jika perusahaan menginginkan pelanggan merasakan kepuasan perusahaan harus membentuk personal dalam perusahaan untuk memiliki kompetensi tinggi dan juga bersifat professional dalam pelayanan kepada pelanggan.

b) Sikap prilaku yang ramah dan sopan santun dalam pelayanan kepada pelanggan juga dirasa pelanggan memiliki pengaruh signifikan terhadap kepuasan yang dirasakan oleh pelanggan. Artinya jika peusahaan ingin pelanggan merasakan kepuasan dalam pelayanan perusahaan harus membentuk pribadi dalam perusahaan untuk selalu bersikap ramah dan mengedepankan sikap sopan santun dalam berkomunikasi dengan pelanggan, agar merasa nyaman dan kepuas atas pelayanan tersebut.

c) Penampilan yang rapi dan menarik juga dapat menampah kepuasan yang di rasakan oleh pelanggan

d) Hubungan antar pribadi berbetentuk sikap simpatik dan memiliki empati dalam pelayan kepada pelanggan juga memiliki pengaruh yang signifikan terhadap kepuasan yang di rasakan oleh pelanggan.

e) Yang menjadi menarik dari penelitian ini adalah variabel produk dimana produk pelayanan dengan sistem Onlie Trading, justru pelanggan online trading menganggap produk online adalah sebagai alat semata di di anggap tidak terlalu berpengaruh signifikan terhadap kepuasan yang mereka rasakan hal tersebut sehingga dari penelitian ini dinilai oleh pelanggan bahwa kepuasan yang 
mereka rasakan tidak terletak pada produk online namun pada pelayanan dan juga harga yang di kenakan kepada pelanggan.

f) Sedangkan untuk variabel tempat, promosi dan bukti fisik tidak memiliki pengaruh signifikan terhadap kepuasan yang di rasakan oleh pelanggan namun variabel tersebut juga mempunyai pengaruh, walaupun pengaruh tersebut tidak signifikan sehingga di perlukan variabel tempat, promosi dan bukti fisik sebagai pendukung variabel orang, harga dan proses untuk menciptakan perasaan puas yang di rasakan oleh pelanggan dalam penjualan produk layanan perantara perdagangan efek yang dilakukan oleh PT. Sucorinvest Central Gani cabang Kediri.

\section{b Saran - Saran}

Berdasarkan hasil penelitian dan kesimpulan yang telah kekemukakan sebagai berikut :

1. Secara praktis.

Bagi PT. Sucorinvest Central Gani cabang Kediri untuk menciptakan kepuasan pelanggan sebaiknya perusahaan lebih menekankan untuk menyiapkan jumlah personal sesuai dengan tugas yang ada di kantor Kediri yang memiliki profesionelisme dan kompetensi di bidangnya, serta membentuk pribadi tersebut menjadi pribadi yang ramah, memiliki sopansantun dalam melayani pelanggan, pribadi yang simpatik dan memiliki empati terhadap permasalahan dan keluhan pelanggan.

Berpenampilan yang rapi dan menarik sehingga dalam proses pelayanan pelanggan akan merasa puas, dalam hal proses pelayanan di pelukan kecepatann dalam pelayanan yang perlu di takankan untuk di tingkatkan karena belum ada dalam penelitian ini, untuk harga cukup membuat pelanggan yang mlakukan investasi akan merasa puas, dan tidak kalah pentingnya untuk tempat, bukti fisik dan produk juga perlu di tingkatkan sebagai bentuk pelayanan kepada pelanggan, karena tidak menuntut kemungkinan variabel ini akan lebih dominan untuk menciptakan perasaan puas dikemudian hari seiring dengan waktu dan perubahan situasi di pasar modal Indonesia. 


\section{Teoritis}

Untuk peneliti selanjutnya, karena di anggap penelitian ini terdapat beberapa yang belum di teliti sehingga perlu di kemabangkan kepuasan yang sudah di teliti terhadap loyalitas pelanggan atau dapat di teliti melalui hubungan antar variabel yang lain sehingga dapat memperkaya penelitian selanjutnya.

3. Keterbatasan penelitian

a. Pengambilan sampel hanya tebatas pada PT. Sucorinvest Central Gani cabang Kediri sehingga hasil penelitian ini tidak dapat di gunakan dasar generalisasi. Akan tetap memberikan informasi yang lebih spesifik pada wilayan Kediri terutama untuk perusahaan perantara pasar modal yang ada di ingin mengembangkan ke wilayah Kediri.

b. Penelitian ini keterbatasan pada pengambilan item pada setiap indikator pada setiap variabel.

c. Penelitian ini tidak mampu untuk mengontrol sepenuhnya kesungguhan dan kejujuran responden agar memilih opsi jawaban sesuai dengan keadaan dan kenyataan yang sebenarnya.

\section{DAFTAR PUSTAKA}

Al-Debi, Hameed \& Al-Waely, Dina Fadhil Jihad, 2015, The Effect of Services Marketing Mix Dimensions on Attrating Customers and Retaining Them : the Case of Jordanian Insurance Companies, International Journal of Marketing Studies, Jordan.

Al-Dmour, Hani, Al-Zu'bi. M.F \& Kakeesh Dana, 2013, The Effect of Services Marketing Mix Elements on Customer-Based Brand Equity : An Empirical Study on Mobile Telecom Service Recipients in Jordan,Internasional Journal of Marketing Studies, Jordan.

Ahmad, Ala Eddin Mohammad Khalaf, et All, 2013, The Impact of Marketing Mix Strategy on Hospital Perforace Measured by Patient Satisfaction: An Empirical Investigation on Jeddah Private Sector Hospital Senior Managers Perspective, International Journal of Marketing Studies, Kingdom of Saudi Arabia.

Aliami, Sri, 2014, Analisis Pengaruh Bauran Pemasaran Jasa dan Citra Perguruan tinggi Terhadap Loyalitas Melalui Kepuasan Mahasiswa Perguruan Tinggi Swasta di Kota Kediri, Disertasi Program Pascasarjana Universitas Merdeka Malang, Malang.

Hariyani, D.P Serfianto, 2010.Buku pinter hukum bisnis Pasar Modal, Transmedia Pustaka, Jakarta. 
Ivy,Jonathan, 2008, A New higher education marketing mix : the 7Ps for MBA Marketing, Emerald Journal Birmingham City University, Birmingham, UK

Kotler, Philip and Amstrong, Gery, 2009, Principle of Marketing, Eleven Edition. New Jersey: Prentice-International.

Kotler, Philip dan Kevin Lane Keller, 2009, Manajemen Pemasaran, Jilid I. Jakarta, Indeks.

.Kotler, Philip dan Amstrong, Gery, 2003, Dasar-Dasar Pemasaran. Diterjemahkan oleh Bambang Sarwiji.Edisi ke-9. Jakarta, PT. Indeks Gramedia.

Olsen, Line Lervik, 2014, Turning Customer Satisfaction measurements into action, CTF Service Research Center, Emerald, Karistad University, Karistad, Sweden.

Priyatno, Dwi, 2012, Belajar praktis analisis parametrik dan non parametric dengan SPSS. Yogyakarta : Gava Media

Sanusi, Anwar. 2014. Metodologi Penelitian Bisnis. Jakarta : Salemba Empat

Seiler, Voker, 2013, The influence of socio- demography variables an customer satisfaction and loyalty in the private bangking industry, Emerald, Otto Beisheim school of management, Vallender, Germany.

Setiadi, Nugroho J, (2010), Perilaku Konsumen: Konsep Dan Impikasi Untuk Strategi Dan Penelitian Pemasaran, Prenada Media Group, Jakarta

Sugiyono, 2012, Metode Penelitian Kuantitatif, Kualitatif, dan R\&D. Bandung: CV Alfabeta.

Sukotjo, Hendri dan Radix, Sumanto A. 2010. Analisa Marketing Mix-7P (Produk, Promotion, Place, Participant, Process, dan Physical Evidence) terhadap Keputusan Pembelian Produk Klinik Kecantikan Teta di Surabaya. Jurnal Mitra Ekonomi dan Manajemen Bisnis Vol 1, No.2.

Su-Mei Lin, 2011," Marketing mix (7P) and performance asserssment of western fast food industry in Taiwan : An application by associating DEMATEL and ANP", Journal of Business Management China University of Technology No. 530 Chung-San, Hu-Ko Township, China.

Wen Wu,Kuang 2006, Service Quality, Customer Satisfaction and Customer loyalty in Consumer Electronic E-Tailers: A Structural Equation medeling approach, Presented in Partial Fulfillment of the Requirements for the Degree of Dotor of Philosophy, lynn University, United States.

Zeithaml, Valarie A and Mary Jo Bitner. 2000. Service Marketing. Singapore: Mc Graw-Hill Companies Inc.: 3-287. 